


\section{CHRONICLES OF CALIFORNIA}

California Pictorial: A History in Contemporary Pictures, 1786 to 1859 , with Descriptive Notes on Pictures and Artists by Jeanne Van Nostrand and Edith M. Coulter

Gold is the Cornerstone by John Walton Caughey

Land in California: The Story of the Mission Lands, Ranchos, Squatters, Mining Claims, Railroad Grants, Land Scrip, Homesteads by W. W. Robinson A Self-governing Dominion: California, 1849-1860 by William Henry Ellison A Literary History of Southern California by Franklin Walker The California Progressives by George E. Mowry

EARTh Song: A Prologue to History by Charles L. Camp

The Chronicles of California comprise a series in which qualified scholars write on well-defined segments of the state's history. Some books follow a particular theme through the whole span from earliest times to the present. Others develop subjects that are chronologically more compact, such as the story of the discovery of gold and the Gold Rush. Conjointly the volumes touch on practically all phases of California's experience.

This series, under the general editorship of Herbert E. Bolton and John W. Caughey, was launched by the University of California as an enduring commemoration of the state's centennial. 
EARTH SONG

A Prologue to History 

University of California Press Berkeley and Los Angeles $195^{2}$

CHARLES L. CAMP

E A R T H

S O NG

A Prologue to History

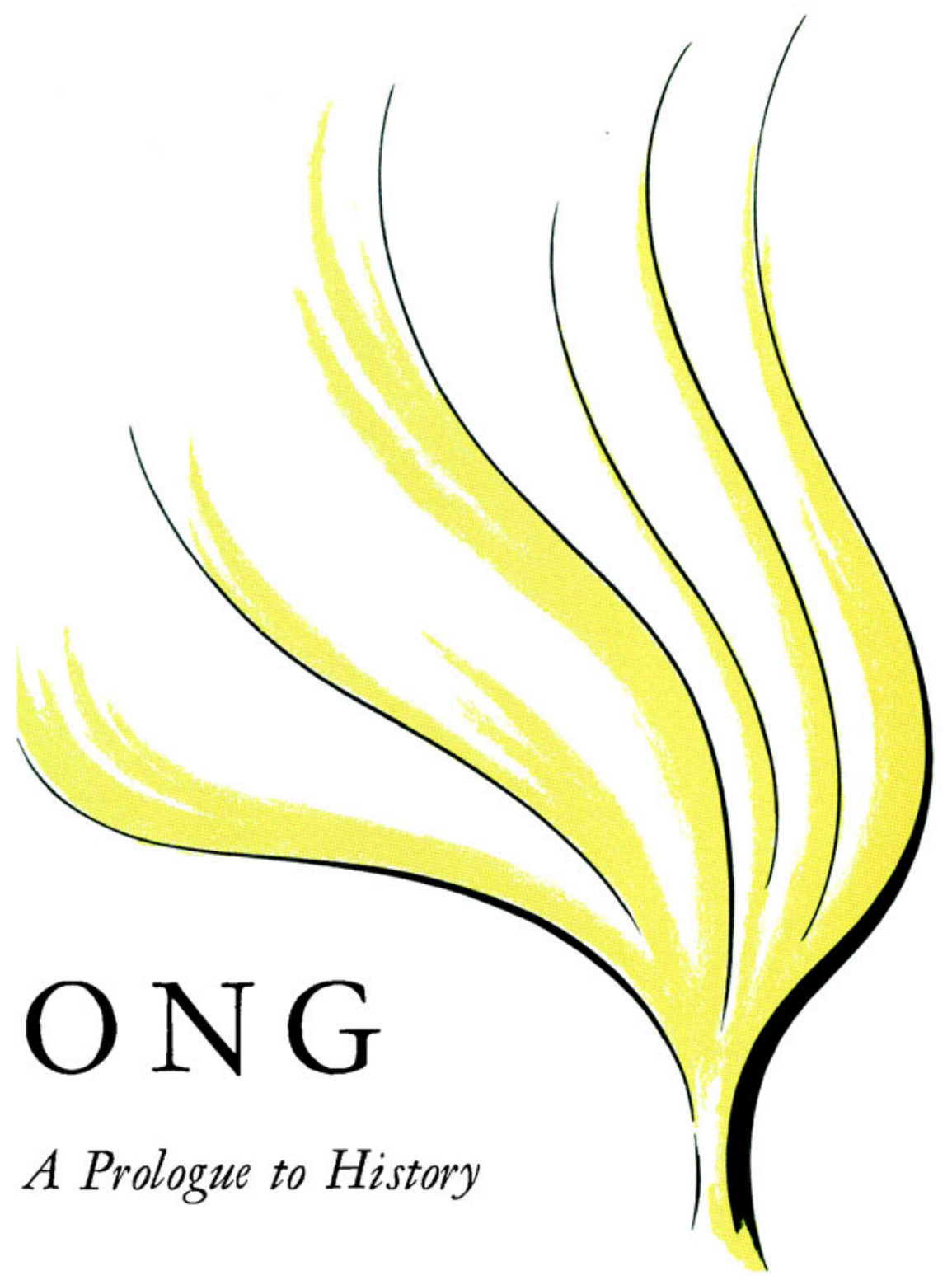


UNIVERSITY OF CALIFORNIA PRESS, BERKELEY AND LOS ANGELES, CALIFORNIA CAMBRIDGE UNIVERSITY PRESS, LONDON, ENGLAND

COPYRIGHT, I952, BY THE REGENTS OF THE UNIVERSITY OF CALIFORNIA PRINTED IN THE UNITED STATES OF AMERICA. DESIGNED BY JOHN B. GOETZ 
To
WILLIAM KING GREGORY

in deep appreciation 